\title{
Surgical Management of Ductal Carcinoma in Situ (DCIS) of the Breast; a large retrospective study from a single institution
}

\author{
Islam M Miligy ${ }^{*}{ }^{*}$ Michael S Toss ${ }^{1 *}$, Hazem Khout ${ }^{2}$, Whisker $\mathrm{L}^{2}$, Burrell $\mathrm{HC}^{2}$, Ian O Ellis ${ }^{1,2,3}$, \\ Andrew R Green ${ }^{1}$, Macmillan RD2 and Emad A Rakha1,2,3
}

\begin{abstract}
${ }_{1}$ Nottingham Breast Cancer Research Centre, Division of Cancer and Stem Cells, School of Medicine, The University of Nottingham, Nottingham City Hospital, UK. ${ }^{2}$ Nottingham Breast Institute, Nottingham University Hospitals NHS Trust, Nottingham City Hospital, UK. 3Department of Histopathology, School of Medicine, The University of Nottingham, Nottingham City Hospital, UK.
\end{abstract}

*Both authors contributed equally to this study

\section{Correspondence:}

Professor Emad Rakha

Department of Histopathology, Nottingham University Hospital NHS Trust, City Hospital Campus, Hucknall Road, Nottingham, NG5 1PB, UK

Tel: (44) 0115-9691169, Fax: (44) 0115-9627768

Email: emad.rakha@nottingham.ac.uk,Emad.rakha@nuh.nhs.uk

\section{Conflict of Interest: No}

Key words: DCIS, management, mastectomy, BCS, re-excision

Running title: Management of DCIS _ 


\section{ABSTRACT}

Background: Management of breast ductal carcinoma in situ (DCIS) has various approaches with distinct institutional specific practice. Here, we review DCIS management in a single institution with emphasise on re-operation rates and outcome. Methods: DCIS cases diagnosed at the Nottingham Breast Institute between 1987 and 2017 were identified $(n=1,249)$. Clinicopathological data was collected. Cases were histologically reviewed, and different factors associated with primary operation selection, re-excision, presence of residual tumour in the re-excision specimens, use of radiotherapy and ipsilateral recurrences were analysed. Results: $34 \%$ of DCIS patients were initially treated by mastectomy and were more frequently symptomatic, of high nuclear tumour grade, size $>40 \mathrm{~mm}$, and associated with comedo necrosis and Paget's disease of the nipple. Further surgery was due to involved or narrow surgical margins. Residual tumour tissue was detected in $53 \%$ of the re-excision specimens. Re-excision rates of patients treated with breast conserving surgery (BCS) were reduced from approximately $70 \%$ to $23 \%$ and the final mastectomy rates decreased from $60 \%$ to $20 \%$. Changes in surgical practice with acceptance of smaller excision margins and more frequent use of local radiotherapy have led to a significant decrease not only in the re-excision rate but also in the final mastectomy rate together with non-significant reduction in 5- and 10-year local recurrence rates. Conclusion: Although BCS is increasingly the preferred primary surgical option for DCIS management, a proportion of low-risk DCIS patients continue to undergo re-excision surgery or completion mastectomy. Despite acceptance of smaller margins, recurrence rate is decreasing. 


\section{INTRODUCTION}

Breast ductal carcinoma in situ (DCIS) represents about $10 \%$ of all breast carcinomas ${ }^{1}$. Its incidence has increased dramatically in the UK since introduction of the mammographic screening programme, and currently it accounts for approximately $20-25 \%$ of mammographically screen detected breast carcinomas 2 . The breakthrough of molecular techniques shows that DCIS is a heterogeneous group of diseases. Such heterogeneity is reflected in tumour behaviour and ideally the management approach needs to be designed accordingly to decrease the risk of progression and/or recurrence ${ }^{3,4}$. Mastectomy was long considered the standard management for DCIS and remains so in certain situations (e.g. extensive disease, those with failed breast conservation, or where there are contraindications to radiotherapy (RT) in high-risk patients) 5,6 . It provides an effective and near total cure rate; however, for most women it is an aggressive over-treatment of a lesion with low mortality risk with potential increased psychosocial morbidity and health economic costs ${ }^{3}$. Breast-conserving surgery (BCS), with or without RT, is offered when DCIS can be removed with an acceptable cosmetic outcome and considered equivalent to mastectomy in terms of overall survival or breast cancer specific survival ${ }^{1}$. However, studies report women treated with BCS have up to $15 \%$ risk of recurrence within 10 years and half of these recurrences are invasive disease with subsequent mortality risk 7,8 . RT following BCS decreases the risk of recurrence to less than $10 \%$ at 10 years although clear guidelines for its indications in specific risk groups continue to be debated 9-13. Over- or under-treatment of DCIS remains a problem and numerous trials have been developed to assess more personalised therapy 14,15 . Various factors affecting outcome of treated DCIS have been analysed and different risk groups can be stratified accordingly, aiding treatment decisions 16. Age at diagnosis, clinical route of presentation, nuclear grade and lesion size, resection margin status are well recognised factors used for this purpose. The Van Nuys prognostic index (VNPI) is a popular risk assessment tool combining patient age, lesion size, nuclear grade and margin status (Supplementary table1) 17,18 .

Optimal extent of free resection margins after BCS is still controversial. A UK survey in 2007 identified that approximately half of surgeons aim for a free margin of more than $2 \mathrm{~mm} 19$. 
In 2016, the Society of Surgical Oncology, American Society for Radiation Oncology and American Society of Clinical Oncology consensus guideline on margins for BCS with wholebreast irradiation in DCIS suggest a $2 \mathrm{~mm}$ free surgical margin 20 . Positive or close margins are the main indication for surgical re-excision or completion mastectomy after primary surgery for DCIS 21-23. In this retrospective study, we review the different management approaches across 30 years in a single institution and the different clinicopathological factors affecting them in a large cohort of women with DCIS diagnosed at the Nottingham Breast Institute between 1987-2017.

\section{PATIENTS AND METHODS}

All pure DCIS cases diagnosed between 1987-2017 at the Nottingham Breast Institute were identified (Table $1, n=1,249$ ). Cases associated with invasive or micro-invasive carcinoma were excluded. Patients with multiple specimens; primary excision and re-excision specimen(s), were considered as a single surgical episode and size of any DCIS identified in the re-excision specimens was added to the size of tumour in the primary excision specimen to calculate the final size. Clinicopathological data including age at diagnosis, mode of DCIS presentation (screen-detected or symptomatic), size of the lesion, nuclear grade, presence of comedo necrosis, DCIS morphological type and associated Paget's disease, was retrieved from patient records. Management options including primary operation type (BCS vs mastectomy), margins status, re-excision surgery and its type, presence of residual DCIS in the re-excised specimens and the final operation together with RT data were also collected.

Resection margin status data was further categorised based on the recent recommendations; i.e. positive margin (tumour on ink), close margin $(<2 \mathrm{~mm}$ ) and negative margin ( $\geq 2 \mathrm{~mm}$ ) 20,24. For comparison purposes; the whole cohort was further split into two groups; those diagnosed between 1987-2008 $(n=803)$ and 2009-2017 $(n=446)$. This was based on the guideline change with regard to margin of excision, soon after 2008, with acceptable free margin after BCS in DCIS of $5 \mathrm{~mm}$ instead of $10 \mathrm{~mm}$ free margin 3 . Although, the service currently follows the new guidelines published in 2016 that recommend $2 \mathrm{~mm}$ as optimal free margin in DCIS, cases managed in 2016 and 2017, in this study, were included in the latter group to avoid bias in statistical analysis. Five and ten-year local recurrence 
free interval (LRFI) was estimated (in months). Five and ten-year local recurrence is defined as any event of ipsilateral tumour recurrence (either as DCIS or invasive disease) occurred after 6 months from the first DCIS surgery and up to 60 and 120 months; respectively.

VNPI was assessed for all cases treated with BCS after the first operation $(n=824)$ and the risk score was estimated.

\section{Statistical analysis}

Statistical analyses were performed using SPSS v21 (Chicago, IL, USA) for Windows. Chisquare test and the multivariate logistic regression model were used to correlate between different clinicopathological factors with primary operation preference, re-excision, type of re- excision, RT and presence of residual tumour tissue in the re-excised specimens. The 5 and 10-year LRFI were compared between both periods by log rank test.

This work obtained ethics approval by the North West - Greater Manchester Central Research Ethics Committee under the title; Nottingham Health Science Biobank (NHSB), reference number 15/NW/0685.

\section{RESULTS}

A total of $945 / 1,249$ women (75\%) diagnosed with DCIS were within the screening age group (50-70 years). High nuclear grade was observed in $61 \%$ of cases, while comedo type necrosis was recorded in two thirds of cases $(67 \%)$. Solid DCIS was the predominant histological type, either in pure form or mixed with other morphological types and represented $58 \%$ of cases. Paget's disease was observed in $56(9 \%)$ cases. 
Regarding DCIS management; $824(66 \%)$ cases were treated primarily with BCS, while mastectomy was performed in 424 cases (34\%). The latter was the first choice in those who presented symptomatically $(p<0.0001)$, diffuse DCIS lesions involving more than one breast quadrant $(p<0.0001)$, DCIS size more than $40 \mathrm{~mm}(p<0.0001)$, high nuclear grade $(p<0.0001)$, associated comedo necrosis $(p<0.0001)$, and solid DCIS $(p=0.030)$ (Table 2$)$.

After primary BCS, 317 (39\%) cases showed positive margins (tumour on ink), while 88 cases $(11 \%)$ showed close margins less than $2 \mathrm{~mm}$. Free safety margin more than $10 \mathrm{~mm}$ was observed in $20 \%$ of cases. Over the entire study period, half of the DCIS cases treated with BCS ( $n=414)$ underwent re-excision. The re-operation was either in the form of another conservative surgery $(n=232)$ or completion mastectomy $(n=182)$, (Table 3$)$.

Several factors influenced the rate of re-excision, including patients younger than 40 years old $(p=0.028)$, symptomatic presentation $(p<0.0001)$, lesions involving more than one breast quadrant $(p=0.003)$, DCIS size more than $40 \mathrm{~mm}(p<0.0001)$, presence of comedo necrosis $(p=0.009)$, positive or close resection margins less than $2 \mathrm{~mm}(p<0.0001)$ and high VNPI $(p<0.0001)$. Moreover, presence of solid and/or micropapillary DCIS either in pure form or with other morphological types was associated with a higher rate of re-excision $(p<0.0001)$. Figure 1 a shows the rate of re-excision as regard to margin status. It is noteworthy that $196(47 \%)$ of those who underwent re-excision were of low or intermediate grade. Moreover, $10 \%$ of low risk VNPI cases had a second operation. Supplementary figure 1 shows the rate of re-excision in context of margin status, tumour grade and risk groups. Table 4 and supplementary table 2 show the detailed association between re-excision and type of re-excision with the clinicopathological variables.

Completion mastectomy was more likely to be recommended for women younger than 40 years old $(p=0.018)$, with symptomatic DCIS $(p<0.0001)$, multiple DCIS lesions or involving more than one breast quadrant $(p=0.005)$, with DCIS more than $4 \mathrm{~cm}$ in maximum diameter $(p<0.0001)$, positive or close resection margin of less than $2 \mathrm{~mm}(p<0.0001)$ and high-risk DCIS according to VNPI $(p<0.0001)$. 
Residual tumour tissue was detected in $218 / 414$ cases $(53 \%)$ who had re-excision surgery. Presence of residual tumour tissue in the re-excised specimens was associated with DCIS presenting symptomatically $(p<0.0001)$, larger tumour size more than $40 \mathrm{~mm}(p<0.0001)$, DCIS with cribriform morphology $(p=0.018)$, positive or close margins less than $2 \mathrm{~mm}$ $(p=0.015)$ and high risk VNPI $(p<0.0001)$. Patients who underwent completion mastectomy showed a higher rate of residual tumour tissue than those who had a second re-excision operation $(p<0.0001)$. Supplementary table 3 shows the different factors associated with the presence of residual tumour tissue in the re-excision or completion mastectomy specimens.

Multivariate logistic regression analysis showed that symptomatic DCIS, extent of the lesion, DCIS size, presence of comedo type necrosis and surgical margin status were the common independent factors affecting the rate of re-excision, type of re-excision and/or presence of residual tumour in the re-excised specimens. Table 5 summarise the multivariate logistic regression results.

VNPI was assessed for all cases treated with BCS after the first operation $(n=824)$ and risk score calculated (mean score was $7.7 \pm 1.7$, range $4-12$ ). Low, moderate and high risk DCIS was observed in $195(25 \%), 470(60 \%)$ and $118(15 \%)$ cases respectively. VNPI could not be assessed in $41(5 \%)$ cases because one or more of the index parameters was missing.

263 out of 642 patients (41\%) treated with BCS as a final surgery received post-operative adjuvant RT. Its use was associated with high risk DCIS features including tumour size more than $40 \mathrm{~mm}(p<0.0001)$, higher tumour grade $(p<0.0001)$, presence of comedo type necrosis $(p<0.0001)$, positive or close surgical margins $(p=0.008)$, and moderate and high risk DCIS (VNPI) $(p<0.0001)$. Increased use of RT over the study period was observed.

Over the period of the study, the management of DCIS showed significant changes with acceptance of smaller margins, improving quality of imaging detection of DCIS and more frequent use of local RT. Figure 1 shows details of the trends of primary and final BCS, RT rate, re-excision rate and local recurrence rate. As the most significant change in the margin status was introduced in 2008 , this time point was used to compare the old and recent series of DCIS in this study. After 2008, a significant reduction in the rate of mastectomy as 
a first operative choice for DCIS management was observed $(p=0.015)$, along with a marked decrease in the rate of re-excision to $37 \%$ compared to $58 \%$ prior to 2008 $(p<0.0001)$ and an increase in the presence of residual DCIS in the re-excised specimens $(p=0.04)$. Re-excision rate in 2017 was $23 \%$.

Importantly, the change in surgical practice after 2008, with acceptance of narrower surgical margins, was not hazardous in terms of the ipsilateral local recurrence rate. In contrast, the 5-year recurrence rate decreased from 5.4\% for DCIS managed between 1987-2008 to $2.2 \%$ for DCIS managed after 2008. The same was observed in the 10 -year recurrence rate which was $8.8 \%$ in the former and dropped to $2.5 \%$ in the latter. However, these differences did not show statistical significance ( $p$ value $=0.223$ and 0.225 , respectively). 
Prior to the early 1990's, the standard treatment for DCIS was mastectomy. However, BCS with adjuvant RT show comparable outcome to mastectomy in terms of recurrence free interval and overall survival and as a result, the rate of mastectomies has declined and BCS predominates 25,26 . In the current study, documenting practice in a single institution over a 30-year period, approximately two thirds of DCIS cases were treated with BCS as a first surgical modality. Mastectomy was the preferred option for patients with symptomatic DCIS, high tumour grade, larger sized tumours $(>40 \mathrm{~mm})$, associated comedo necrosis and those involving more than one quadrant of the breast. Over the period of the study, there was not only an increase in the rates of initial BCS but also a significant decline in the re-excision and final mastectomy rates and more importantly in the ipsilateral local recurrences rate. Although a change in the local practice occurred in 2008, in which margin width of $5 \mathrm{~mm}$ was accepted instead of $10 \mathrm{~mm}$, and a recent change of practice in 2016 in which $2 \mathrm{~mm}$ margin was adopted, the frequency of BCS, re-excision rates and local recurrence rates showed gradual change over time rather than a sudden transition at this certain time point. This may reflect the impact of several factors including the improvement of imaging quality with better assessment of DCIS size and extent, quality of surgery, and the growing use of local RT.

The current study demonstrates the radiological and pathological indications for BCS and the factors associated with the decision to perform additional therapeutic operations. The predominant factor in deciding BCS is the extent of the disease. Patient choice is also a contributing factor as evidenced by the NHS Breast Screening Programme where patient choice accounts for about $11 \%$ of mastectomies for DCIS 27 . Recently, in the UK and US, the rate of mastectomy has increased particularly in young women perceived at high risk of further breast cancer events 6,28. In a report on 8,000 DCIS cases included in the Sloane Project and treated between 2003 and 2012 the rate of attempted BCS was 79\% and successful BCS was $68 \% 27,29$. Achieving success at BCS for DCIS remains a challenge and it continues to be the case that a woman with DCIS is at least as likely to have a mastectomy as a woman with invasive breast cancer (IBC). It is also reported that the re-excision rates 
after BCS as a treatment for DCIS is higher than re-excisions for IBC. Furthermore, invasive disease accompanying DCIS has higher re-operation rates than pure invasive disease 30,31 .

The need to perform further surgery, re-excision or completion mastectomy, is governed predominantly by what is regarded as a minimum free resection margin. Positive margins is partly due to radiologic under-estimation of DCIS size which can occur in over $50 \%$ of cases 29,32. Other studies, similar to the current findings, have shown that the diffuse DCIS growth patterns such as micropapillary and cribriform types, high nuclear grade DCIS with comedo type necrosis and high risk VNPI are factors associated with an increased rate of reexcisions ${ }^{31-34}$.

The current study shows that half of the patients with DCIS who underwent re-excision, due to positive or close surgical margins, were of low and intermediate grade. This practice might have an impact on the pending outcome of recent trials for more conservative management of low risk DCIS 14,35 . If safe, such strategies could significantly reduce reoperation and mastectomy rates.

In this study, half of the re-excised specimens were free of residual tumour, even though some cases were reported to have tumour on ink after the primary excision. Such a finding perhaps illustrates the controversy in pathological evaluation 24 . Presence of residual DCIS was correlated to other adverse clinicopathological parameters i.e. symptomatic presentation, larger tumour size, DCIS with cribriform and micropapillary morphology. Previous studies were performed to establish a margin index based on tumour size and the closest surgical margin to show its association with presence of residual tumour tissue after re-excision, but this did not show significant association 36,37. Another study showed that the extent of margin involvement either focal or diffuse as well as the number of involved ducts in the closest margin were the main factors associated with presence of residual DCIS in the re-excision specimens ${ }^{22}$. In our case series, an increased rate of residual tumour tissue in the re-excised specimens was found after 2008 perhaps reflecting a better overall strategy for further surgery. 
Determining the optimal free margin for breast conservation remains a challenge particularly in pure DCIS. The Society of Surgical Oncology-American Society for Radiation Oncology has published new guidelines for the optimal margin in invasive disease and recommends no tumour on ink as a negative margin as there is no evidence that wider clear margins reduce ipsilateral recurrence ${ }^{38}$. In DCIS, the same group published consensus guidelines suggesting $2 \mathrm{~mm}$ as a standard for adequate surgical margin. Systematic review and meta-analysis of 20 studies showed that negative margins minimise the risk of ipsilateral recurrence by $50 \%$ compared with positive margins defined as tumour on ink. A $2 \mathrm{~mm}$ margin minimises the risk of recurrence compared with smaller negative margins ${ }^{39-41}$. However, the agreement on these recommendations is different between centres and the choice of optimal margins depends mainly on the surgeons' practice and methods of margin assessment by pathologists which was supported by the current National Institute for Health and Care Excellence (NICE) guidelines ${ }^{42}$. Accepting closer margins of excision is a means of reducing re-operation rates, as has been shown in invasive disease ${ }^{43}$. However, planning a wider macroscopic margin in higher risk cases or tailoring the scrutiny of margin assessment to the risk factors are other strategies.

The acceptable optimal margin ranged from $1 \mathrm{~mm}$ to $>10 \mathrm{~mm}$. In the current study, we grouped cases according to margin status using different classification schemes. Close surgical margins less than $2 \mathrm{~mm}$ were significantly associated with an increased rate of reexcision and presence of residual tumour tissue in the re-excised specimens which is consistent with other studies 22,44,45. Interestingly, change in surgical practice with acceptance of narrower free margin in patients treated conservatively did not increase the recurrence rate. This indicates better risk stratification, adjuvant radiotherapy (RT) selection and individualised management for patients based on constellation of all clinicopathological factors.

All large prospective trials to evaluate the impact of adjuvant RT after DCIS BCS showed a $50 \%$ reduction in recurrence rate with adjuvant RT 10,46,47. No specific group of patients were identified where RT could be safely avoided, hence the continued debate over RT indications after BCS. In routine practice, only about $30-50 \%$ of BCS treated patients 
receive adjuvant RT 48 and the recommendation for it differs between radiotherapists as well as institutions ${ }^{49}$. Overall in our series, $41 \%$ of BCS treated patients were offered postoperative RT. It was a common practice in our centre before 2008 that no further treatment was suggested for patients with clear pathological margins $10 \mathrm{~mm}$ or more. After previous analysis of patient outcome, selective RT was introduced 50. RT was then recommended after BCS to those with high grade DCIS, women younger than 50 years old and lesions more than $30 \mathrm{~mm}$, regardless of tumour grade, following a multidisciplinary team discussion 3. Patients who undergo mastectomy will not receive postoperative RT regardless of the age, nuclear grade or lesion size.

Conclusion: This study addresses the long-term experience of a single institution with DCIS management over a 30-year period. Over this time rates of successful BCS have improved but avoiding the need for second therapeutic operations remains a challenge. The dominant risk factors for failed BCS and for disease in re-excision or completion mastectomy specimens are young age ( $<40$ years), symptomatic presentation, presence of comedo necrosis, and larger tumour size ( $>40 \mathrm{~mm})$.

\section{ACKNOWLEDGEMENTS}

We thank the Nottingham Health Science Biobank.

\section{REFERENCES}

1. Sakorafas GH, Farley DR, Peros G. Recent advances and current controversies in the management of DCIS of the breast. Cancer treatment reviews. 2008;34(6):483-497.

2. Ernster VL, Ballard-Barbash R, Barlow WE, et al. Detection of ductal carcinoma in situ in women undergoing screening mammography. Journal of the National Cancer Institute. 2002;94(20):1546-1554.

3. Mathew J, Karia R, Morgan DA, et al. Factors influencing local control in patients undergoing breast conservation surgery for ductal carcinoma in situ. Breast (Edinburgh, Scotland). 2017;31:181-185.

4. Fallowfield L, Francis A, Thompson AM. EFfects of standard treatments for ductal carcinoma in situ-making informed choices. JAMA Oncology. 2016;2(3):396-397.

5. Surgical guidelines for the management of breast cancer. European journal of surgical oncology : the journal of the European Society of Surgical Oncology and the British Association of Surgical Oncology. 2009;35 Suppl 1:1-22. 
6. Rutter CE, Park HS, Killelea BK, Evans SB. Growing Use of Mastectomy for Ductal Carcinoma-In Situ of the Breast Among Young Women in the United States. Annals of surgical oncology. 2015;22(7):2378-2386.

7. Silverstein MJ, Barth A, Poller DN, et al. Ten-year results comparing mastectomy to excision and radiation therapy for ductal carcinoma in situ of the breast. European Journal of Cancer. 1995;31(9):1425-1427.

8. Van Zee KJ, Subhedar P, Olcese C, Patil S, Morrow M. Relationship Between Margin Width and Recurrence of Ductal Carcinoma In Situ: Analysis of 2996 Women Treated With Breast-conserving Surgery for 30 Years. Ann Surg. 2015;262(4):623-631.

9. Farante G, Orecchia R, Luini A, et al. Are all patients with ductal carcinoma in situ of the breast candidates for radiotherapy after breast conservative treatment? Institute of European Oncology Guidelines. The breast journal. 2014;20(4):431-433.

10. Donker M, Litiere S, Werutsky G, et al. Breast-conserving treatment with or without radiotherapy in ductal carcinoma In Situ: 15-year recurrence rates and outcome after a recurrence, from the EORTC 10853 randomized phase III trial. Journal of clinical oncology : official journal of the American Society of Clinical Oncology. 2013;31(32): 4054-4059.

11. Kim T, Park HK, Lee $\mathrm{KH}$, et al. Is radiotherapy necessary for intermediate risk ductal carcinoma in situ after breast conserving surgery? Springerplus. 2014;3:405.

12. McCormick B, Winter K, Hudis C, et al. RTOG 9804: a prospective randomized trial for good-risk ductal carcinoma in situ comparing radiotherapy with observation. Journal of clinical oncology : official journal of the American Society of Clinical Oncology. 2015;33(7):709-715.

13. Rampaul RS, Valasiadou P, Pinder SE, et al. Wide local excision with $10 \mathrm{~mm}$ clearance without radiotherapy for DCIS. European Journal of Cancer. 2001;37:15.

14. Elshof LE, Tryfonidis K, Slaets L, et al. Feasibility of a prospective, randomised, openlabel, international multicentre, phase III, non-inferiority trial to assess the safety of active surveillance for low risk ductal carcinoma in situ - The LORD study. European journal of cancer (Oxford, England : 1990). 2015;51(12):1497-1510.

15. Francis A, Thomas J, Fallowfield L, et al. Addressing overtreatment of screen detected DCIS; the LORIS trial. European journal of cancer (Oxford, England : 1990). 2015;51(16):2296-2303.

16. Silverstein MJ. Current controversies in ductal carcinoma in situ of the breast: summary from the Lynn Sage Breast Cancer Symposium. J Am Coll Surg. 2003;197(1): 115-118.

17. Silverstein MJ. The University of Southern California/Van Nuys prognostic index for ductal carcinoma in situ of the breast. American journal of surgery. 2003;186(4): 337-343.

18. Boland GP, Chan KC, Knox WF, Roberts SA, Bundred NJ. Value of the Van Nuys Prognostic Index in prediction of recurrence of ductal carcinoma in situ after breastconserving surgery. Br J Surg. 2003;90(4):426-432.

19. Young OE, Valassiadou K, Dixon M. A Review of Current Practices in Breast Conservation Surgery in the UK. Annals of The Royal College of Surgeons of England. 2007;89(2): 118-123.

20. Morrow M, Van Zee KJ, Solin LJ, et al. Society of Surgical Oncology-American Society for Radiation Oncology-American Society of Clinical Oncology Consensus Guideline on Margins for Breast-Conserving Surgery With Whole-Breast Irradiation in Ductal Carcinoma in Situ. Practical Radiation Oncology. 2016;6(5):287-295.

21. Dillon MF, MC Dermott EW, O'Doherty A, Quinn CM, Hill AD, O'Higgins N. Factors affecting successful breast conservation for ductal carcinoma in situ. Annals of surgical oncology. 2007;14(5):1618-1628.

22. Wei S, Kragel CP, Zhang K, Hameed O. Factors associated with residual disease after initial breast-conserving surgery for ductal carcinoma in situ. Human pathology. 2012;43(7):986-993.

23. Holland PA, Gandhi A, Knox WF, Wilson M, Baildam AD, Bundred NJ. The importance of complete excision in the prevention of local recurrence of ductal carcinoma in situ. British Journal of Cancer. 1998;77(1):110-114.

24. Toss MS, Pinder SE, Green AR, et al. Breast conservation in ductal carcinoma in situ (DCIS): what defines optimal margins? Histopathology. 2017;70(5):681-692. 
25. Boyages M.B.B.S J, Delaney M.B.B.S G, Taylor M.B.B.S R. Predictors of local recurrence after treatment of ductal carcinoma in situ. Cancer. 1999;85(3):616-628.

26. Zujewski JA, Harlan LC, Morrell DM, Stevens JL. Ductal carcinoma in situ: trends in treatment over time in the US. Breast cancer research and treatment. 2011;127(1): 251-257.

27. Thomas J, Hanby A, Pinder SE, et al. Adverse surgical outcomes in screen-detected ductal carcinoma in situ of the breast. European journal of cancer (Oxford, England : 1990). 2014;50(11):1880-1890.

28. Shiyanbola $\mathrm{OO}$, Sprague BL, Hampton JM, et al. Emerging trends in surgical and adjuvant radiation therapies among women diagnosed with ductal carcinoma in situ. Cancer. 2016;15(122(18)):2810-2818.

29. Thomas J, Evans A, Macartney J, et al. Radiological and pathological size estimations of pure ductal carcinoma in situ of the breast, specimen handling and the influence on the success of breast conservation surgery: a review of 2564 cases from the Sloane Project. British Journal of Cancer. 2010;102(2):285-293.

30. Jeevan $\mathrm{R}$, Cromwell DA, Trivella $M$, et al. Reoperation rates after breast conserving surgery for breast cancer among women in England: retrospective study of hospital episode statistics. BMJ (Clinical research ed). 2012;345:e4505.

31. Dieterich M, Dieterich H, Moch H, Rosso C. Re-excision Rates and Local Recurrence in Breast Cancer Patients Undergoing Breast Conserving Therapy. Geburtshilfe und Frauenheilkunde. 2012;72(11):1018-1023.

32. Dixon JM, Newlands C, Dodds C, et al. Association between underestimation of tumour size by imaging and incomplete excision in breast-conserving surgery for breast cancer. The British journal of surgery. 2016;103(7):830-838.

33. Merrill AL, Coopey SB, Tang R, et al. Implications of New Lumpectomy Margin Guidelines for Breast-Conserving Surgery: Changes in Reexcision Rates and Predicted Rates of Residual Tumor. Annals of surgical oncology. 2016;23(3):729-734.

34. McCahill LE, Single RM, Aiello Bowles EJ, et al. Variability in reexcision following breast conservation surgery. Jama. 2012;307(5):467-475.

35. Pilewskie M, Stempel M, Rosenfeld H, Eaton A, Van Zee KJ, Morrow M. Do LORIS Trial Eligibility Criteria Identify a Ductal Carcinoma In Situ Patient Population at Low Risk of Upgrade to Invasive Carcinoma? Annals of surgical oncology. 2016;23(11):3487-3493.

36. Fisher CS, Klimberg VS, Khan S, Gao F, Margenthaler JA. Margin index is not a reliable tool for predicting residual disease after breast-conserving surgery for DCIS. Annals of surgical oncology. 2011;18(11):3155-3159.

37. Margenthaler JA, Gao F, Klimberg VS. Margin index: a new method for prediction of residual disease after breast-conserving surgery. Annals of surgical oncology. 2010;17(10):2696-2701.

38. Moran MS, Schnitt SJ, Giuliano AE, et al. Society of Surgical Oncology-American Society for Radiation Oncology consensus guideline on margins for breast-conserving surgery with whole-breast irradiation in stages I and II invasive breast cancer. Journal of clinical oncology : official journal of the American Society of Clinical Oncology. 2014;32(14):1507-1515.

39. Morrow M. Breast conservation and negative margins: how much is enough? Breast (Edinburgh, Scotland). 2009;18 Suppl 3:S84-86.

40. Azu M, Abrahamse P, Katz SJ, Jagsi R, Morrow M. What is an adequate margin for breast-conserving surgery? Surgeon attitudes and correlates. Annals of surgical oncology. 2010;17(2):558-563.

41. Morrow M, Van Zee KJ, Solin LJ, et al. Society of Surgical Oncology-American Society for Radiation Oncology-American Society of Clinical Oncology Consensus Guideline on Margins for Breast-Conserving Surgery With Whole-Breast Irradiation in Ductal Carcinoma In Situ. Journal of clinical oncology : official journal of the American Society of Clinical Oncology. 2016;34(33):4040-4046.

42. National Institute for Health and Care Excellence. Early and locally advanced breast cancer: diagnosis and management, [A] Evidence reviews for surgery to the breast, NICE guideline NG101. 2018.

43. Schulman AM, Mirrielees JA, Leverson G, Landercasper J, Greenberg C, Wilke LG. Reexcision Surgery for Breast Cancer: An Analysis of the American Society of Breast 
Surgeons (ASBrS) MasterySM Database Following the SSO-ASTRO "No Ink on Tumor" Guidelines. Annals of surgical oncology. 2017;24(1):52-58.

44. Schouten van der Velden AP, Van de Vrande SL, Boetes C, Bult P, Wobbes T. Residual disease after re-excision for tumour-positive surgical margins in both ductal carcinoma in situ and invasive carcinoma of the breast: The effect of time. Journal of surgical oncology. 2007;96(7):569-574.

45. Neuschatz AC, DiPetrillo T, Steinhoff $M$, et al. The value of breast lumpectomy margin assessment as a predictor of residual tumor burden in ductal carcinoma in situ of the breast. Cancer. 2002;94(7):1917-1924.

46. Holmberg L, Garmo H, Granstrand B, et al. Absolute risk reductions for local recurrence after postoperative radiotherapy after sector resection for ductal carcinoma in situ of the breast. Journal of clinical oncology : official journal of the American Society of Clinical Oncology. 2008;26(8):1247-1252.

47. Dodwell D, Clements K, Lawrence G, et al. Radiotherapy following breast-conserving surgery for screen-detected ductal carcinoma in situ: indications and utilisation in the UK. Interim findings from the Sloane Project. British Journal of Cancer. 2007;97(6): 725-729.

48. Ward EM, DeSantis CE, Lin CC, et al. Cancer statistics: Breast cancer in situ. CA: A Cancer Journal for Clinicians. 2015;65(6):481-495.

49. Practice guideline for the management of ductal carcinoma in-situ of the breast (DCIS). J Am Coll Surg. 2007;205(1):145-161.

50. Blamey RW MR, Rampaul RS, Valassiadou P, Wahedna Y, Sibbering M, Pinder SE. DCIS The Nottingham exerience. In: M S, ed. Ductal Carcinoma In-Situ 2nd Edition. LWW publishing; 2002. 
Figure 1

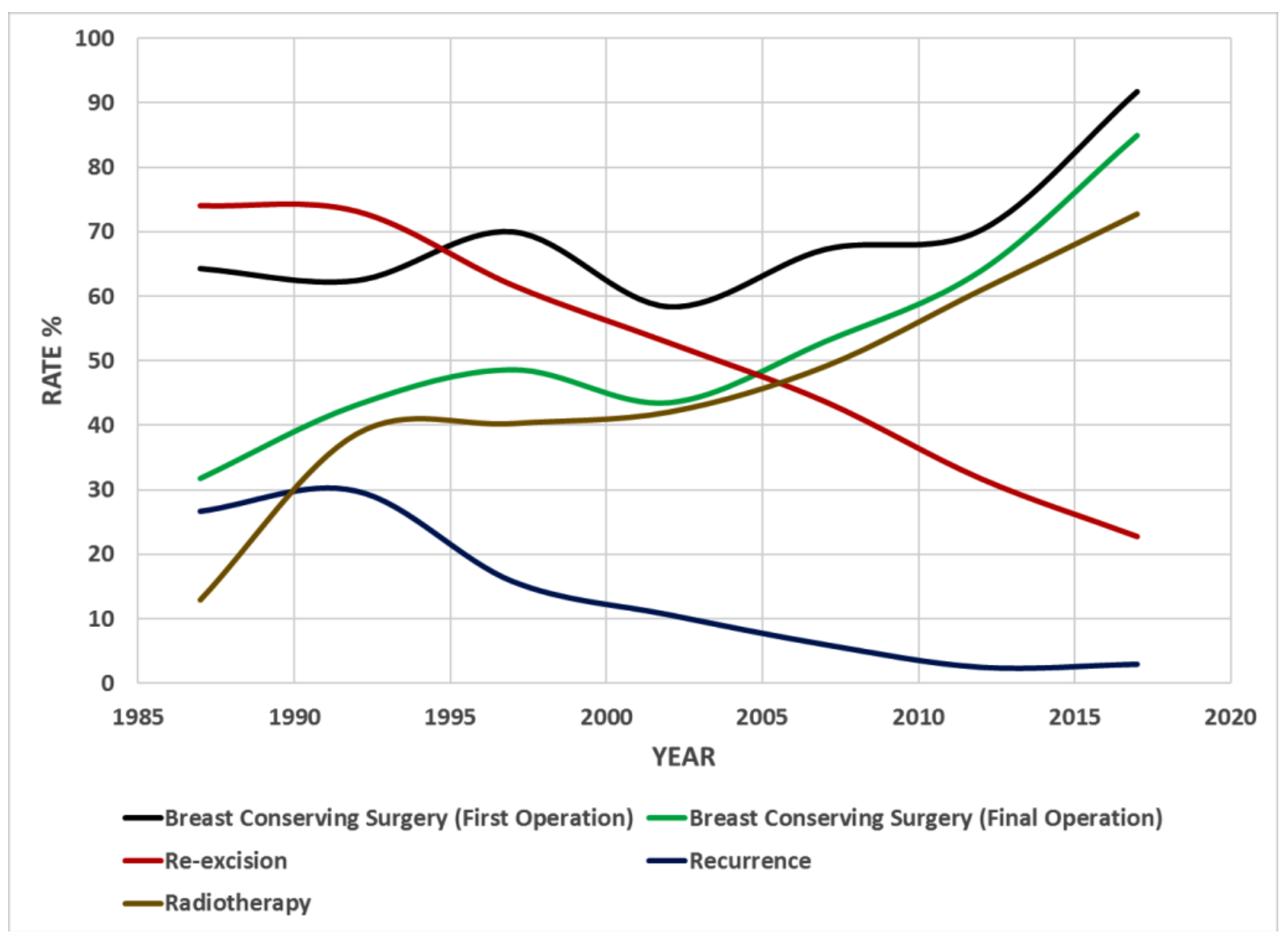

Figure 1: The annual rates, over the period between 1987-2017, of: A) Breast conserving surgery (BCS); shows the higher rates of BCS as a primary surgical choice over the years, B) Shows the comparable rates of final BCS after re-excisions. Obviously over the last 10 years the rates of BCS exceed the rates of mastectomy. C) Postoperative adjuvant radiotherapy; a significant increase of radiotherapy use post-operatively after 2000 is observed. D) Re-excision and E) Recurrence after primary BCS; A significant decrease in both is observed over the last 10 years. 
Table 1: Clinicopathological parameters of the whole primary DCIS cohort stratified by time period 


\begin{tabular}{|c|c|c|c|c|}
\hline Parameter & $\begin{array}{l}\text { Total } \\
\text { N (\%) }\end{array}$ & $\begin{array}{l}\text { DCIS Diagnosed } \\
\begin{array}{c}1987-2008 \\
(n=803) \\
N(\%)\end{array}\end{array}$ & $\begin{array}{l}\text { DCIS diagnosed } \\
2009-2017 \\
(n=446) \\
N(\%)\end{array}$ & $\begin{array}{c}X^{2} \\
\text { P-value }\end{array}$ \\
\hline $\begin{array}{l}\text { Age } * \\
\quad<40 \\
\quad 40 \text { to } 60 \\
>60\end{array}$ & $\begin{array}{l}32(3) \\
688(55) \\
529(42)\end{array}$ & $\begin{array}{l}24(3) \\
467(58) \\
312(39)\end{array}$ & $\begin{array}{l}8(2) \\
221(49) \\
217(49)\end{array}$ & $\begin{array}{l}11.9 \\
\mathbf{0 . 0 0 3}\end{array}$ \\
\hline $\begin{array}{l}\text { Presentation } \\
\text { Symptomatic } \\
\text { Screening }\end{array}$ & $\begin{array}{l}501(40) \\
748(60)\end{array}$ & $\begin{array}{l}351(44) \\
452(56)\end{array}$ & $\begin{array}{l}150(34) \\
296(66)\end{array}$ & $\begin{array}{l}11.8 \\
\mathbf{0 . 0 0 1}\end{array}$ \\
\hline $\begin{array}{l}\text { DCIS Site } * * \\
\text { Localised } \\
\text { Diffuse }\end{array}$ & $\begin{array}{l}929(85) \\
160(15)\end{array}$ & $\begin{array}{l}590(88) \\
79(12)\end{array}$ & $\begin{array}{l}339(81) \\
81(19)\end{array}$ & $\begin{array}{l}11.5 \\
\mathbf{0 . 0 0 1}\end{array}$ \\
\hline $\begin{array}{l}\text { Tumour Size * } \\
\quad<16 \mathrm{~mm} \\
16 \text { to } 40 \mathrm{~mm} \\
>40 \mathrm{~mm}\end{array}$ & $\begin{array}{l}457(37) \\
484(39) \\
301(24)\end{array}$ & $\begin{array}{l}308(39) \\
304(38) \\
184(23)\end{array}$ & $\begin{array}{l}149(33) \\
180(41) \\
117(26)\end{array}$ & $\begin{array}{l}3.6 \\
0.160\end{array}$ \\
\hline $\begin{array}{l}\text { Tumour Grade } \\
\text { Low } \\
\text { Intermediate } \\
\text { High }\end{array}$ & $\begin{array}{l}156(12) \\
333(27) \\
760(61)\end{array}$ & $\begin{array}{l}109(14) \\
185(23) \\
509(64)\end{array}$ & $\begin{array}{l}47(11) \\
148(33) \\
251(56)\end{array}$ & $\begin{array}{l}16.8 \\
<\mathbf{0 . 0 0 0 1}\end{array}$ \\
\hline $\begin{array}{l}\text { Comedo necrosis } \\
\text { No } \\
\text { Yes }\end{array}$ & $\begin{array}{l}409(33) \\
840(67)\end{array}$ & $\begin{array}{l}280(35) \\
523(65)\end{array}$ & $\begin{array}{l}129(29) \\
317(71)\end{array}$ & $\begin{array}{l}4.6 \\
\mathbf{0 . 0 3 2}\end{array}$ \\
\hline $\begin{array}{l}\text { Solid DCIS } \\
\text { No } \\
\text { Pure } \\
\text { Mixed with other types }\end{array}$ & $\begin{array}{l}529(42) \\
291(23) \\
429(35)\end{array}$ & $\begin{array}{l}406(50) \\
164(20) \\
233(30)\end{array}$ & $\begin{array}{l}123(28) \\
127(28) \\
196(44)\end{array}$ & $\begin{array}{l}62.3 \\
<\mathbf{0 . 0 0 0 1}\end{array}$ \\
\hline $\begin{array}{l}\text { Cribriform DCIS } \\
\text { No } \\
\text { Pure } \\
\text { Mixed with other types }\end{array}$ & $\begin{array}{l}649(52) \\
114(9) \\
486(39)\end{array}$ & $\begin{array}{l}444(55) \\
75(10) \\
284(35)\end{array}$ & $\begin{array}{l}205(46) \\
39(9) \\
202(45)\end{array}$ & $\begin{array}{l}12.1 \\
\mathbf{0 . 0 0 2}\end{array}$ \\
\hline $\begin{array}{l}\text { Papillary DCIS } \\
\text { No } \\
\text { Pure } \\
\text { Mixed with other types }\end{array}$ & $\begin{array}{l}1127(90) \\
42(3) \\
80(7)\end{array}$ & $\begin{array}{l}729(91) \\
26(3) \\
48(6)\end{array}$ & $\begin{array}{l}398(89) \\
16(4) \\
32(7)\end{array}$ & $\begin{array}{l}0.8 \\
0.663\end{array}$ \\
\hline $\begin{array}{l}\text { Micropapillary DCIS } \\
\text { No } \\
\text { Pure } \\
\text { Mixed with other types }\end{array}$ & $\begin{array}{l}916(73) \\
79(7) \\
254(20)\end{array}$ & $\begin{array}{l}594(74) \\
53(7) \\
156(19)\end{array}$ & $\begin{array}{l}322(72) \\
26(6) \\
98(22)\end{array}$ & $\begin{array}{l}1.3 \\
0.520\end{array}$ \\
\hline $\begin{array}{l}\text { Associated Paget's Disease } \\
\text { No } \\
\text { Yes }\end{array}$ & $\begin{array}{l}559(91) \\
56(9)\end{array}$ & $\begin{array}{l}399(90) \\
43(10)\end{array}$ & $\begin{array}{l}160(93) \\
13(7)\end{array}$ & $\begin{array}{l}0.7 \\
0.361\end{array}$ \\
\hline $\begin{array}{l}\text { Management (First Operation) } \\
\text { Mastectomy } \\
\text { Breast conserving surgery (BCS) }\end{array}$ & $\begin{array}{l}424(34) \\
824(66)\end{array}$ & $\begin{array}{l}292(36) \\
510(64)\end{array}$ & $\begin{array}{l}132(30) \\
314(70)\end{array}$ & $\begin{array}{l}5.9 \\
\mathbf{0 . 0 1 5}\end{array}$ \\
\hline $\begin{array}{l}\text { Margin width } * * * \\
\text { Positive (Tumour on ink) } \\
<2 \mathrm{~mm} \\
\geq 2 \mathrm{~mm} \\
\text { Unknown }\end{array}$ & $\begin{array}{l}317(39) \\
88(11) \\
382(46) \\
37(4)\end{array}$ & $\begin{array}{l}240(47) \\
36(7) \\
202(40) \\
32(6)\end{array}$ & $\begin{array}{l}77(24) \\
52(17) \\
180(57) \\
5(2)\end{array}$ & $\begin{array}{l}72.5 \\
<\mathbf{0 . 0 0 0 1}\end{array}$ \\
\hline $\begin{array}{l}\text { Re excision } * * * \\
\text { Yes } \\
\text { No }\end{array}$ & $\begin{array}{l}414(50) \\
410(50)\end{array}$ & $\begin{array}{l}298(58) \\
212(42)\end{array}$ & $\begin{array}{l}116(37) \\
198(63)\end{array}$ & $\begin{array}{l}35.9 \\
<\mathbf{0 . 0 0 0 1}\end{array}$ \\
\hline
\end{tabular}




\begin{tabular}{|c|c|c|c|c|}
\hline $\begin{array}{l}\text { Type of re-excision } * * * \\
\text { Re excision } \\
\text { Mastectomy }\end{array}$ & $\begin{array}{l}232(56) \\
182(44)\end{array}$ & $\begin{array}{l}159(53) \\
139(47)\end{array}$ & $\begin{array}{l}73(63) \\
43(37)\end{array}$ & $\begin{array}{l}3.1 \\
0.078\end{array}$ \\
\hline $\begin{array}{l}\text { Residual Tumour } * * * \\
\text { No } \\
\text { Yes }\end{array}$ & $\begin{array}{l}196(47) \\
218(53)\end{array}$ & $\begin{array}{l}150(50) \\
148(50)\end{array}$ & $\begin{array}{l}46(40) \\
70(60)\end{array}$ & \begin{tabular}{|l}
3.8 \\
0.051
\end{tabular} \\
\hline $\begin{array}{l}\text { Management (Final Operation) } \\
\text { Mastectomy } \\
\text { BCS }\end{array}$ & $\begin{array}{l}606(49) \\
642(51)\end{array}$ & $\begin{array}{l}431(54) \\
371(46)\end{array}$ & $\begin{array}{l}175(39) \\
271(61)\end{array}$ & $\begin{array}{l}24.1 \\
<0.0001\end{array}$ \\
\hline $\begin{array}{l}\text { Radiotherapy } * * * * \\
\text { Yes } \\
\text { No }\end{array}$ & $\begin{array}{l}263(41) \\
379(59)\end{array}$ & $\begin{array}{l}92(25) \\
279(75)\end{array}$ & $\begin{array}{l}171(63) \\
100(37)\end{array}$ & $\begin{array}{l}127.1 \\
<\mathbf{0 . 0 0 0 1}\end{array}$ \\
\hline $\begin{array}{l}\text { VNPI (after } 1^{\text {st }} \text { operation) } * * * \\
\text { Low risk } \\
\text { Moderate risk } \\
\text { High risk }\end{array}$ & $\begin{array}{l}195(25) \\
470(60) \\
118(15)\end{array}$ & $\begin{array}{l}105(22) \\
288(61) \\
81(17)\end{array}$ & $\begin{array}{l}90(29) \\
182(59) \\
37(12)\end{array}$ & $\begin{array}{l}7.1 \\
\mathbf{0 . 0 3 0}\end{array}$ \\
\hline
\end{tabular}

DCIS: Ductal carcinoma in situ; $\mathrm{N}$ : Number; $\mathrm{X}^{2}$ : Chi square, $\mathrm{P}$ values in bold are significant

*Age and size were categorised according to Van Nuys Prognostic Index (VNPI)

** Site; Localised: DCIS is involving one quadrant, diffuse: DCIS is in more than one quadrant

$* * *$ Refers to patients treated primarily with BCS (first operation)

$* * * *$ Refers to patients treated by BCS (final operation) 
Table 2: Clinicopathological factors associated with the selection of type of primary surgery for DCIS management stratified by time period

\begin{tabular}{|c|c|c|c|c|c|c|c|c|c|}
\hline \multirow[t]{2}{*}{ Parameter } & \multicolumn{2}{|c|}{$\begin{array}{c}\text { DCIS Diagnosed } \\
1987-2008 \\
\text { N }(\%)\end{array}$} & \multirow{2}{*}{$\begin{array}{c}X^{2} \\
p- \\
\text { value }\end{array}$} & \multicolumn{2}{|c|}{$\begin{array}{c}\text { DCIS diagnosed } \\
2009-2017 \\
\text { N }(\%)\end{array}$} & \multirow{2}{*}{$\begin{array}{c}X^{2} \\
p- \\
\text { value }\end{array}$} & \multicolumn{2}{|c|}{$\begin{array}{c}\text { Total } \\
\text { N (\%) }\end{array}$} & \multirow{2}{*}{$\begin{array}{c}\mathbf{X}^{2} \\
\boldsymbol{p}- \\
\text { value }\end{array}$} \\
\hline & BCS & $\begin{array}{c}\text { Mastect } \\
\text { omy }\end{array}$ & & BCS & $\begin{array}{c}\text { Mastect } \\
\text { omy }\end{array}$ & & BCS & $\begin{array}{c}\text { Mastecto } \\
\text { my }\end{array}$ & \\
\hline $\begin{array}{l}\text { Age } \\
\quad<40 \\
\quad 40 \text { to } 60 \\
>60\end{array}$ & $\begin{array}{l}13(54) \\
297 \\
(64) \\
200 \\
(64)\end{array}$ & $\begin{array}{l}11(46) \\
170(36) \\
111(36)\end{array}$ & $\begin{array}{l}0.9 \\
0.610\end{array}$ & $\begin{array}{l}5(63) \\
150 \\
(68) \\
159 \\
(73)\end{array}$ & $\begin{array}{l}3(37) \\
71(32) \\
58(27)\end{array}$ & $\begin{array}{l}1.8 \\
0.412\end{array}$ & $\begin{array}{l}18(56) \\
447 \\
(65) \\
359 \\
(68)\end{array}$ & $\begin{array}{l}14(44) \\
241(35) \\
169(32)\end{array}$ & $\begin{array}{l}2.6 \\
0.271\end{array}$ \\
\hline $\begin{array}{l}\text { Presentation } \\
\text { Symptomatic } \\
\text { Screening }\end{array}$ & $\begin{array}{l}204 \\
(58) \\
306 \\
(68)\end{array}$ & $\begin{array}{l}146(42) \\
146(32)\end{array}$ & $\begin{array}{l}7.6 \\
\mathbf{0 . 0 0 6}\end{array}$ & $\begin{array}{l}84(56) \\
230 \\
(78)\end{array}$ & $\begin{array}{l}66(44) \\
66(22)\end{array}$ & $\begin{array}{l}22.5 \\
<0.00 \\
01\end{array}$ & $\begin{array}{l}288 \\
(58) \\
536 \\
(72)\end{array}$ & $\begin{array}{l}212(42) \\
212(28)\end{array}$ & $\begin{array}{l}26.4 \\
<0.00 \\
01\end{array}$ \\
\hline $\begin{array}{l}\text { Site } \\
\text { Localised } \\
\text { Diffuse }\end{array}$ & $\begin{array}{l}365 \\
(62) \\
30(38)\end{array}$ & $\begin{array}{l}224(38) \\
49(62)\end{array}$ & $\begin{array}{l}51.7 \\
<0.00 \\
01\end{array}$ & $\begin{array}{l}250 \\
(74) \\
45(56)\end{array}$ & $\begin{array}{l}89(26) \\
36(44)\end{array}$ & $\begin{array}{l}10.5 \\
0.005\end{array}$ & $\begin{array}{l}615 \\
(66) \\
75(47)\end{array}$ & $\begin{array}{l}313(34) \\
85(53)\end{array}$ & $\begin{array}{l}48.6 \\
<0.00 \\
01\end{array}$ \\
\hline $\begin{array}{l}\text { Size } \\
\quad<16 \mathrm{~mm} \\
16 \text { to } 40 \mathrm{~mm} \\
>40 \mathrm{~mm}\end{array}$ & $\begin{array}{l}256 \\
(83) \\
175 \\
(58) \\
75 \\
(41)\end{array}$ & $\begin{array}{l}52(17) \\
129(42) \\
109(59)\end{array}$ & $\begin{array}{l}96.9 \\
<0.00 \\
01\end{array}$ & $\begin{array}{l}133 \\
(89) \\
134 \\
(74) \\
47 \\
(40)\end{array}$ & $\begin{array}{l}16(11) \\
46(26) \\
70(60)\end{array}$ & $\begin{array}{l}78.1 \\
<0.00 \\
01\end{array}$ & $\begin{array}{l}389 \\
(85) \\
309 \\
(64) \\
122 \\
(41)\end{array}$ & $\begin{array}{l}68(15) \\
175(36) \\
179(59)\end{array}$ & $\begin{array}{l}162.5 \\
<0.00 \\
01\end{array}$ \\
\hline $\begin{array}{l}\text { Grade } \\
\text { Low } \\
\text { Intermediate } \\
\text { High }\end{array}$ & $\begin{array}{l}92(84) \\
133 \\
(72) \\
285 \\
(56)\end{array}$ & $\begin{array}{l}17(16) \\
51(28) \\
224(44)\end{array}$ & $\begin{array}{l}39.1 \\
<0.00 \\
01\end{array}$ & $\begin{array}{l}41(87) \\
116 \\
(78) \\
157 \\
(63)\end{array}$ & $\begin{array}{l}6(13) \\
32(22) \\
94(37)\end{array}$ & $\begin{array}{l}18.3 \\
<0.00 \\
01\end{array}$ & $\begin{array}{l}133 \\
(85) \\
249 \\
(75) \\
442 \\
(58)\end{array}$ & $\begin{array}{l}23(15) \\
83(25) \\
318(42)\end{array}$ & $\begin{array}{l}58.6 \\
<0.00 \\
01\end{array}$ \\
\hline $\begin{array}{l}\text { Comedo necrosis } \\
\text { No } \\
\text { Yes }\end{array}$ & $\begin{array}{l}215 \\
(77) \\
295 \\
(56)\end{array}$ & $\begin{array}{l}64(23) \\
228(44)\end{array}$ & $\begin{array}{l}33.5 \\
<0.00 \\
01\end{array}$ & $\begin{array}{l}109 \\
(85) \\
205 \\
(65)\end{array}$ & $\begin{array}{l}20(15) \\
112(35)\end{array}$ & $\begin{array}{l}17.3 \\
<0.00 \\
01\end{array}$ & $\begin{array}{l}324 \\
(79) \\
500 \\
(60)\end{array}$ & $\begin{array}{l}84(21) \\
340(40)\end{array}$ & $\begin{array}{l}48.4 \\
<0.00 \\
01\end{array}$ \\
\hline $\begin{array}{l}\text { Solid DCIS } \\
\text { No } \\
\text { Pure } \\
\text { Mixed with other } \\
\text { types }\end{array}$ & $\begin{array}{l}273 \\
(67) \\
103 \\
(63) \\
134 \\
(58)\end{array}$ & $\begin{array}{l}132(33) \\
61(37) \\
99(42)\end{array}$ & $\begin{array}{l}6.3 \\
\mathbf{0 . 0 4 3}\end{array}$ & $\begin{array}{l}95(77) \\
89(70) \\
130 \\
(66)\end{array}$ & $\begin{array}{l}28(23) \\
38(30) \\
66(34)\end{array}$ & $\begin{array}{l}4.3 \\
0.115\end{array}$ & $\begin{array}{l}368 \\
(70) \\
192 \\
(66) \\
264 \\
(62)\end{array}$ & $\begin{array}{l}160(30) \\
99(34) \\
165(38)\end{array}$ & $\begin{array}{l}7.1 \\
\mathbf{0 . 0 3 0}\end{array}$ \\
\hline $\begin{array}{l}\text { Cribriform DCIS } \\
\text { No } \\
\text { Pure } \\
\text { Mixed with other } \\
\text { types }\end{array}$ & $\begin{array}{l}274 \\
(62) \\
59(79) \\
177 \\
(62)\end{array}$ & $\begin{array}{l}169(38) \\
16(21) \\
107(38)\end{array}$ & $\begin{array}{l}8.1 \\
0.017\end{array}$ & $\begin{array}{l}143 \\
(70) \\
33(85) \\
138 \\
(68)\end{array}$ & $\begin{array}{l}62(30) \\
6(15) \\
64(32)\end{array}$ & $\begin{array}{l}4.2 \\
0.120\end{array}$ & $\begin{array}{l}417 \\
(64) \\
92(81) \\
315 \\
(65)\end{array}$ & $\begin{array}{l}231(36) \\
22(19) \\
171(35)\end{array}$ & $\begin{array}{l}12.1 \\
0.002\end{array}$ \\
\hline $\begin{array}{l}\text { Papillary DCIS } \\
\text { No } \\
\text { Pure } \\
\text { Mixed with other } \\
\text { types }\end{array}$ & $\begin{array}{l}458 \\
(63) \\
21(84) \\
31(65)\end{array}$ & $\begin{array}{l}271(37) \\
4(16) \\
17(35)\end{array}$ & $\begin{array}{l}4.7 \\
0.095\end{array}$ & $\begin{array}{l}270 \\
(68) \\
15(94) \\
29(91)\end{array}$ & $\begin{array}{l}128(32) \\
1(6) \\
3(9)\end{array}$ & $\begin{array}{l}11.7 \\
\mathbf{0 . 0 0 3}\end{array}$ & $\begin{array}{l}728 \\
(65) \\
36(88) \\
60(75)\end{array}$ & $\begin{array}{l}399(35) \\
5(12) \\
20(25)\end{array}$ & $\begin{array}{l}12.6 \\
\mathbf{0 . 0 0 2}\end{array}$ \\
\hline
\end{tabular}




\begin{tabular}{|c|c|c|c|c|c|c|c|c|c|}
\hline $\begin{array}{l}\text { Micropapillary } \\
\text { DCIS } \\
\text { No } \\
\text { Pure } \\
\text { Mixed with other } \\
\text { types }\end{array}$ & $\begin{array}{l}391 \\
(66) \\
33(62) \\
86(55)\end{array}$ & $\begin{array}{l}202(34) \\
20(38) \\
70(45)\end{array}$ & $\begin{array}{l}6.3 \\
\mathbf{0 . 0 4 3}\end{array}$ & $\begin{array}{l}236 \\
(73) \\
14(54) \\
64(65)\end{array}$ & $\begin{array}{l}86(27) \\
12(46) \\
34(35)\end{array}$ & $\begin{array}{l}5.9 \\
0.052\end{array}$ & $\begin{array}{l}627 \\
(69) \\
47(60) \\
150 \\
(59)\end{array}$ & $\begin{array}{l}288(31) \\
32(40) \\
104(41)\end{array}$ & $\begin{array}{l}9.6 \\
\mathbf{0 . 0 0 8}\end{array}$ \\
\hline $\begin{array}{l}\text { Associated } \\
\text { Paget's } \\
\text { No } \\
\text { Yes }\end{array}$ & $\begin{array}{l}143 \\
(36) \\
7(16)\end{array}$ & $\begin{array}{l}256(64) \\
36(84)\end{array}$ & $\begin{array}{l}6.6 \\
\mathbf{0 . 0 1 0}\end{array}$ & $\begin{array}{l}40(25) \\
3(23)\end{array}$ & $\begin{array}{l}120(75) \\
10(77)\end{array}$ & $\begin{array}{l}0.1 \\
0.877\end{array}$ & $\begin{array}{l}183 \\
(33) \\
10(18)\end{array}$ & $\begin{array}{l}376(67) \\
46(82)\end{array}$ & $\begin{array}{l}5.2 \\
\mathbf{0 . 0 2 2}\end{array}$ \\
\hline
\end{tabular}

DCIS: Ductal carcinoma in situ; N: Number; $\mathrm{X}^{2}$ : Chi square, BCS: Breast conserving surgery, $p$ values in bold are significant 
Table 3: Detailed surgical management of the DCIS cases as a whole cohort

\begin{tabular}{|c|c|c|c|c|}
\hline \multicolumn{5}{|c|}{ Surgical management } \\
\hline $\begin{array}{l}\text { Primary } \\
\text { operation }\end{array}$ & $\begin{array}{c}\text { Mastectomy } \\
(n=424) \\
(34 \%)\end{array}$ & \multicolumn{3}{|c|}{$\begin{array}{c}\text { BCS } \\
(n=824) \\
66 \%\end{array}$} \\
\hline \multirow{3}{*}{ Re excisions } & & \multicolumn{2}{|c|}{$\begin{array}{l}\text { Yes }(n=414) \\
(50 \%)\end{array}$} & \multirow{3}{*}{$\begin{array}{l}\text { No re-excision }(n=410) \\
(50 \%)\end{array}$} \\
\hline & & Mastectomy & Re-excision & \\
\hline & & $n=182(44 \%)$ & $n=232(56 \%)$ & \\
\hline $\begin{array}{l}\text { Final } \\
\text { operation }\end{array}$ & $\begin{array}{l}\text { Mastectomy } \\
\quad(n=606) \\
(49 \%)\end{array}$ & & & $\begin{array}{c}\text { BCS } \\
(n=642) \\
(51 \%)\end{array}$ \\
\hline
\end{tabular}

BCS: Breast conserving surgery; n: number 
Table 4: Clinicopathological factors associated with re excision after primary treatment with breast conserving surgery stratified by time period

\begin{tabular}{|c|c|c|c|c|c|c|c|c|c|}
\hline \multirow[t]{2}{*}{ Parameter } & \multicolumn{2}{|c|}{$\begin{array}{c}\text { DCIS Diagnosed } \\
1987-2008 \\
\text { N }(\%)\end{array}$} & \multirow{2}{*}{$\begin{array}{c}\mathbf{X}^{2} \\
\boldsymbol{p}- \\
\text { value }\end{array}$} & \multicolumn{2}{|c|}{$\begin{array}{c}\text { DCIS diagnosed } \\
2009-2017 \\
\text { N }(\%)\end{array}$} & \multirow{2}{*}{$\begin{array}{c}X^{2} \\
p- \\
\text { value }\end{array}$} & \multicolumn{2}{|c|}{ Total } & \multirow{2}{*}{$\begin{array}{c}X^{2} \\
p- \\
\text { value }\end{array}$} \\
\hline & No & Yes & & No & Yes & & No & Yes & \\
\hline $\begin{array}{l}\text { Age } \\
\quad<40 \\
40 \text { to } 60 \\
>60\end{array}$ & $\begin{array}{l}3(23) \\
113 \\
(38) \\
96(48)\end{array}$ & $\begin{array}{l}10(77) \\
184(62) \\
104(52)\end{array}$ & $\begin{array}{l}6.7 \\
0.034\end{array}$ & $\begin{array}{l}3(60) \\
95(63) \\
100 \\
(63)\end{array}$ & $\begin{array}{l}2(40) \\
55(37) \\
59(37)\end{array}$ & $\begin{array}{l}0.1 \\
0.987\end{array}$ & $\begin{array}{l}6(33) \\
208 \\
(46) \\
196 \\
(55)\end{array}$ & $\begin{array}{l}12(67) \\
239 \\
(54) \\
163 \\
(45)\end{array}$ & $\begin{array}{l}7.2 \\
\mathbf{0 . 0 2 8}\end{array}$ \\
\hline $\begin{array}{l}\text { Presentation } \\
\text { Symptomatic } \\
\text { Screening }\end{array}$ & $\begin{array}{l}65(32) \\
147 \\
(48)\end{array}$ & $\begin{array}{l}139(68) \\
159(52)\end{array}$ & $\begin{array}{l}13.2 \\
<0.00 \\
01\end{array}$ & $\begin{array}{l}41(49) \\
157 \\
(68)\end{array}$ & $\begin{array}{l}43(51) \\
73(32)\end{array}$ & $\begin{array}{l}9.9 \\
\mathbf{0 . 0 0 2}\end{array}$ & $\begin{array}{l}106 \\
(37) \\
304 \\
(57)\end{array}$ & $\begin{array}{l}182 \\
(63) \\
232 \\
(43)\end{array}$ & $\begin{array}{l}29.7 \\
<0.00 \\
01\end{array}$ \\
\hline $\begin{array}{l}\text { Site } \\
\text { Localised } \\
\text { Diffuse }\end{array}$ & $\begin{array}{l}157 \\
(43) \\
13(43)\end{array}$ & $\begin{array}{l}208(57) \\
17(57)\end{array}$ & $\begin{array}{l}1.6 \\
0.459\end{array}$ & $\begin{array}{l}169 \\
(68) \\
21(47)\end{array}$ & $\begin{array}{l}81(32) \\
24(53)\end{array}$ & $\begin{array}{l}10.9 \\
\mathbf{0 . 0 0 4}\end{array}$ & $\begin{array}{l}326 \\
(53) \\
34 \\
(45)\end{array}$ & $\begin{array}{l}289 \\
(47) \\
41(55)\end{array}$ & $\begin{array}{l}11.5 \\
\mathbf{0 . 0 0 3}\end{array}$ \\
\hline $\begin{array}{l}\text { Size } \\
<16 \mathrm{~mm} \\
16 \text { to } 40 \mathrm{~mm} \\
>40 \mathrm{~mm}\end{array}$ & $\begin{array}{l}133 \\
(52) \\
66(38) \\
10(13)\end{array}$ & $\begin{array}{l}123(48) \\
109(62) \\
65(87)\end{array}$ & $\begin{array}{l}37.1 \\
<0.00 \\
01\end{array}$ & $\begin{array}{l}112 \\
(84) \\
69(51) \\
17(36)\end{array}$ & $\begin{array}{l}21(16) \\
65(49) \\
30(64)\end{array}$ & $\begin{array}{l}47.8 \\
<0.00 \\
01\end{array}$ & $\begin{array}{l}245 \\
(63) \\
135 \\
(44) \\
27 \\
(22)\end{array}$ & $\begin{array}{l}144 \\
(37) \\
174 \\
(56) \\
95(78)\end{array}$ & $\begin{array}{l}69.1 \\
<0.00 \\
01\end{array}$ \\
\hline $\begin{array}{l}\text { Grade } \\
\text { Low } \\
\text { Intermediate } \\
\text { High }\end{array}$ & $\begin{array}{l}34(37) \\
57(44) \\
121 \\
(42)\end{array}$ & $\begin{array}{l}58(63) \\
76(56) \\
164(58)\end{array}$ & $\begin{array}{l}0.9 \\
0.610\end{array}$ & $\begin{array}{l}27(66) \\
68(59) \\
103 \\
(66)\end{array}$ & $\begin{array}{l}14(34) \\
48(41) \\
54(34)\end{array}$ & $\begin{array}{l}1.6 \\
0.459\end{array}$ & $\begin{array}{l}61 \\
(46) \\
125 \\
(50) \\
224 \\
(51)\end{array}$ & $\begin{array}{l}72(54) \\
124 \\
(50) \\
218 \\
(49)\end{array}$ & $\begin{array}{l}0.9 \\
0.614\end{array}$ \\
\hline $\begin{array}{l}\text { Comedo necrosis } \\
\text { No } \\
\text { Yes }\end{array}$ & $\begin{array}{l}81(38) \\
131 \\
(44)\end{array}$ & $\begin{array}{l}134(62) \\
164(56)\end{array}$ & $\begin{array}{l}2.3 \\
0.128\end{array}$ & $\begin{array}{l}62(57) \\
136 \\
(66)\end{array}$ & $\begin{array}{l}47(43) \\
69(34)\end{array}$ & $\begin{array}{l}2.7 \\
0.098\end{array}$ & $\begin{array}{l}143 \\
(44) \\
267 \\
(53)\end{array}$ & $\begin{array}{l}181 \\
(56) \\
233 \\
(47)\end{array}$ & $\begin{array}{l}6.7 \\
0.009\end{array}$ \\
\hline $\begin{array}{l}\text { Solid DCIS } \\
\text { No } \\
\text { Pure } \\
\text { Mixed with other } \\
\text { types }\end{array}$ & $\begin{array}{l}98(36) \\
55(53) \\
59(44)\end{array}$ & $\begin{array}{l}175(64) \\
48(47) \\
75(56)\end{array}$ & $\begin{array}{l}9.8 \\
\mathbf{0 . 0 0 7}\end{array}$ & $\begin{array}{l}59(62) \\
67(75) \\
72(55)\end{array}$ & $\begin{array}{l}36(38) \\
22(25) \\
58(45)\end{array}$ & $\begin{array}{l}9.1 \\
\mathbf{0 . 0 1 1}\end{array}$ & $\begin{array}{l}157 \\
(43) \\
122 \\
(64) \\
131 \\
(50)\end{array}$ & $\begin{array}{l}211 \\
(57) \\
70(36) \\
133 \\
(50)\end{array}$ & $\begin{array}{l}22.1 \\
<0.00 \\
01\end{array}$ \\
\hline $\begin{array}{l}\text { Cribriform DCIS } \\
\text { No } \\
\text { Pure } \\
\text { Mixed with other } \\
\text { types }\end{array}$ & $\begin{array}{l}108 \\
(39) \\
27(46) \\
77(44)\end{array}$ & $\begin{array}{l}166(61) \\
32(54) \\
100(56)\end{array}$ & $\begin{array}{l}1.2 \\
0.543\end{array}$ & $\begin{array}{l}97(68) \\
23(70) \\
78(56)\end{array}$ & $\begin{array}{l}46(32) \\
10(30) \\
60(44)\end{array}$ & $\begin{array}{l}4.5 \\
0.103\end{array}$ & $\begin{array}{l}205 \\
(49) \\
50 \\
(54) \\
155 \\
(49)\end{array}$ & $\begin{array}{l}212 \\
(51) \\
42(46) \\
160 \\
(51)\end{array}$ & $\begin{array}{l}0.9 \\
0.646\end{array}$ \\
\hline
\end{tabular}




\begin{tabular}{|c|c|c|c|c|c|c|c|c|c|}
\hline $\begin{array}{l}\text { Papillary DCIS } \\
\text { No } \\
\text { Pure } \\
\text { Mixed with other } \\
\text { types }\end{array}$ & $\begin{array}{l}188 \\
(41) \\
10(48) \\
14(45)\end{array}$ & $\begin{array}{l}270(59) \\
11(52) \\
17(55)\end{array}$ & $\begin{array}{l}0.5 \\
0.766\end{array}$ & $\begin{array}{l}168 \\
(62) \\
13(87) \\
17(59)\end{array}$ & $\begin{array}{l}102(38) \\
2(13) \\
12(41)\end{array}$ & $\begin{array}{l}3.9 \\
0.141\end{array}$ & $\begin{array}{l}356 \\
(49) \\
23 \\
(64) \\
31 \\
(52)\end{array}$ & $\begin{array}{l}372 \\
(51) \\
13(36) \\
29(48)\end{array}$ & $\begin{array}{l}3.2 \\
0.204\end{array}$ \\
\hline $\begin{array}{l}\text { Micropapillary } \\
\text { DCIS } \\
\text { No } \\
\text { Pure } \\
\text { Mixed with other } \\
\text { types }\end{array}$ & $\begin{array}{l}175 \\
(45) \\
6(18) \\
31(36)\end{array}$ & $\begin{array}{l}216(55) \\
27(82) \\
55(64)\end{array}$ & $\begin{array}{l}10.1 \\
0.006\end{array}$ & $\begin{array}{l}160 \\
(68) \\
7(50) \\
31(48)\end{array}$ & $\begin{array}{l}76(32) \\
7(50) \\
33(52)\end{array}$ & $\begin{array}{l}9.2 \\
\mathbf{0 . 0 1 0}\end{array}$ & $\begin{array}{l}335 \\
(53) \\
13 \\
(28) \\
62 \\
(41)\end{array}$ & $\begin{array}{l}292 \\
(47) \\
34(72) \\
88(59)\end{array}$ & $\begin{array}{l}16.8 \\
<0.00 \\
\mathbf{0 1}\end{array}$ \\
\hline $\begin{array}{l}\text { Margin width } \\
\text { Positive (tumour } \\
\text { on ink) } \\
<2 \mathrm{~mm} \\
\geq 2 \mathrm{~mm}\end{array}$ & $\begin{array}{l}8(3) \\
9(25) \\
165 \\
(82)\end{array}$ & $\begin{array}{l}232(97) \\
27(75) \\
37(18)\end{array}$ & $\begin{array}{l}318.7 \\
<0.00 \\
01\end{array}$ & $\begin{array}{l}3(4) \\
18(35) \\
175 \\
(97)\end{array}$ & $\begin{array}{l}74(96) \\
34(65) \\
5(3)\end{array}$ & $\begin{array}{l}225.1 \\
<0.00 \\
\mathbf{0 1}\end{array}$ & $\begin{array}{l}11(3) \\
27 \\
(31) \\
340 \\
(89)\end{array}$ & $\begin{array}{l}306 \\
(97) \\
61(69) \\
42(11)\end{array}$ & $\begin{array}{l}543.7 \\
<0.00 \\
01\end{array}$ \\
\hline $\begin{array}{l}\text { VNPI (1st } \\
\text { operation) } \\
\text { Low risk } \\
\text { Moderate risk } \\
\text { High risk }\end{array}$ & $\begin{array}{l}73(70) \\
103 \\
(36) \\
5(6)\end{array}$ & $\begin{array}{l}32(30) \\
185(64) \\
76(94)\end{array}$ & $\begin{array}{l}108.9 \\
<0.00 \\
\mathbf{0 1}\end{array}$ & $\begin{array}{l}82(91) \\
109 \\
(60) \\
5(13)\end{array}$ & $\begin{array}{l}8(9) \\
73(40) \\
32(87)\end{array}$ & $\begin{array}{l}71.3 \\
<0.00 \\
\mathbf{0 1}\end{array}$ & $\begin{array}{l}155 \\
(79) \\
212 \\
(45) \\
10(8)\end{array}$ & $\begin{array}{l}40(21) \\
258 \\
(55) \\
108 \\
(92)\end{array}$ & $\begin{array}{l}168.9 \\
<0.00 \\
01\end{array}$ \\
\hline
\end{tabular}

DCIS: Ductal carcinoma in situ; VNPI: Van Nuys Prognostic Index; N: Number; $\mathrm{X}^{2}$ : Chi square, $p$ values in bold are significant 
Table 5: Multivariate logistic regression model analysis showing the association between the various clinicopathological parameters and; a) selection of type of primary surgery for DCIS management (BCS versus mastectomy), b) re-excision after primary treatment with BCS, c) type of the re-excision surgery either another conservative operation or completion mastectomy and, d) presence of residual tumour tissue in the re excision specimens

\begin{tabular}{|c|c|c|c|c|c|c|c|c|c|}
\hline \multirow{2}{*}{ Parameter } & \multicolumn{3}{|c|}{$\begin{array}{c}\text { DCIS Diagnosed } \\
1987-2008\end{array}$} & \multicolumn{3}{|c|}{$\begin{array}{c}\text { DCIS Diagnosed } \\
2009-2017\end{array}$} & \multicolumn{3}{|c|}{ Whole Cohort } \\
\hline & $\begin{array}{l}\text { Hazard } \\
\text { Ratio }\end{array}$ & $95 \% \mathrm{CI}$ & $\begin{array}{c}\mathrm{p}- \\
\text { value }\end{array}$ & $\begin{array}{l}\text { Hazard } \\
\text { Ratio }\end{array}$ & $95 \% \mathrm{CI}$ & $\mathrm{p}$-value & $\begin{array}{l}\text { Hazard } \\
\text { Ratio }\end{array}$ & $95 \% \mathrm{CI}$ & $\mathrm{p}$-value \\
\hline Patient age & 2.1 & $0.6-6.8$ & $\begin{array}{c}0.26 \\
1\end{array}$ & 2.2 & $0.2-22.5$ & 0.512 & 2.3 & $0.8-6.3$ & 0.121 \\
\hline $\begin{array}{l}\text { DCIS } \\
\text { presentation }\end{array}$ & 0.7 & $0.4-1.1$ & $\begin{array}{c}0.13 \\
4\end{array}$ & 1.1 & $0.5-2.6$ & 0.823 & 0.8 & $0.5-1.2$ & 0.275 \\
\hline $\begin{array}{l}\text { DCIS site } \\
\text { (extent) }\end{array}$ & 2.2 & $1.1-4.4$ & $\begin{array}{c}0.03 \\
0\end{array}$ & 0.9 & $0.3-2.2$ & 0.773 & 1.7 & $0.9-2.8$ & 0.058 \\
\hline DCIS size & 1.2 & $0.6-2.2$ & $\begin{array}{c}0.63 \\
2\end{array}$ & 1.8 & $0.7-4.5$ & 0.219 & 1.2 & $0.7-1.8$ & 0.527 \\
\hline $\begin{array}{l}\text { DCIS Nuclear } \\
\text { grade }\end{array}$ & 1.8 & $1.1-3.2$ & $\begin{array}{c}0.04 \\
2\end{array}$ & 0.9 & $0.1-6.1$ & 0.923 & 1.5 & $0.9-2.5$ & 0.082 \\
\hline $\begin{array}{l}\text { Comedo } \\
\text { necrosis }\end{array}$ & 1.7 & $0.9-2.9$ & $\begin{array}{c}0.07 \\
5\end{array}$ & 6.4 & $1.8-23.1$ & 0.004 & 2.3 & $1.4-3.8$ & 0.001 \\
\hline $\begin{array}{l}\text { DCIS } \\
\text { Histological } \\
\text { type }\end{array}$ & 1.5 & $0.9-2.4$ & $\begin{array}{c}0.07 \\
6\end{array}$ & 0.6 & $0.2-1.5$ & 0.279 & 1.2 & $0.8-1.8$ & 0.381 \\
\hline $\begin{array}{l}\text { Presence of } \\
\text { Paget's Disease }\end{array}$ & 2.5 & $1.1-6.2$ & $\begin{array}{c}0.04 \\
5\end{array}$ & 0.5 & $0.1-2.4$ & 0.402 & 1.8 & $0.8-3.9$ & 0.130 \\
\hline
\end{tabular}

$p$ values in bold are significant

*DCIS extent refers to either localised DCIS involving one quadrant or diffuse that involves more than one breast quadrant. 
B)

\begin{tabular}{|c|c|c|c|c|c|c|c|c|c|}
\hline \multirow{2}{*}{ Parameter } & \multicolumn{3}{|c|}{$\begin{array}{c}\text { DCIS Diagnosed } \\
1987-2008\end{array}$} & \multicolumn{3}{|c|}{$\begin{array}{c}\text { DCIS Diagnosed } \\
2009-2017\end{array}$} & \multicolumn{3}{|c|}{ Whole Cohort } \\
\hline & $\begin{array}{c}\text { Hazard } \\
\text { Ratio }\end{array}$ & $95 \% \mathrm{CI}$ & $\begin{array}{c}\mathrm{p}- \\
\text { value }\end{array}$ & $\begin{array}{c}\text { Hazard } \\
\text { Ratio }\end{array}$ & $95 \% \mathrm{CI}$ & $\mathrm{p}$-value & $\begin{array}{c}\text { Hazard } \\
\text { Ratio }\end{array}$ & $95 \% \mathrm{CI}$ & $\mathrm{p}$-value \\
\hline Patient age & 2.2 & $0.1-68.3$ & $\begin{array}{c}0.66 \\
1\end{array}$ & 0.5 & $0.2-1.3$ & 0.155 & 0.9 & $0.1-8.6$ & 0.974 \\
\hline $\begin{array}{l}\text { DCIS } \\
\text { presentation }\end{array}$ & 1.2 & $0.5-2.9$ & $\begin{array}{c}0.64 \\
6\end{array}$ & 0.2 & $0.1-0.9$ & 0.041 & 1.2 & $0.6-2.2$ & 0.635 \\
\hline $\begin{array}{l}\text { DCIS site } \\
\text { (extent) }\end{array}$ & 0.1 & $0.01-0.2$ & $\begin{array}{c}0.00 \\
1\end{array}$ & 1.4 & $0.2-6.7$ & 0.711 & 0.2 & $0.1-0.5$ & 0.002 \\
\hline DCIS size & 1.5 & $0.3-8.1$ & $\begin{array}{c}0.64 \\
4\end{array}$ & 2.1 & $0.3-13.7$ & 0.439 & 2.8 & $1.1-6.9$ & 0.026 \\
\hline $\begin{array}{l}\text { DCIS Nuclear } \\
\text { grade }\end{array}$ & 0.4 & $0.1-1.2$ & $\begin{array}{c}0.11 \\
4\end{array}$ & 1.7 & $0.2-14.7$ & 0.649 & 0.6 & $0.2-1.5$ & 0.280 \\
\hline $\begin{array}{l}\text { Comedo } \\
\text { necrosis }\end{array}$ & 0.6 & $0.2-1.6$ & $\begin{array}{c}0.33 \\
6\end{array}$ & 0.3 & $0.1-1.3$ & 0.103 & 0.4 & $0.2-0.9$ & 0.046 \\
\hline $\begin{array}{l}\text { DCIS } \\
\text { Histological } \\
\text { type }\end{array}$ & 1.2 & $0.5-2.8$ & $\begin{array}{c}0.60 \\
5\end{array}$ & 1.6 & $0.5-4.9$ & 0.409 & 1.4 & $0.8-2.4$ & 0.282 \\
\hline Margin status & 0.1 & $0.07-0.2$ & $\begin{array}{l}<0.0 \\
001\end{array}$ & 0.1 & $0.03-0.2$ & $\begin{array}{c}<0.00 \\
01\end{array}$ & 0.1 & $0.02-0.2$ & $\begin{array}{c}<0.000 \\
1\end{array}$ \\
\hline
\end{tabular}

$p$ values in bold are significant

C)

\begin{tabular}{|c|c|c|c|c|c|c|c|c|c|}
\hline \multirow{2}{*}{ Parameter } & \multicolumn{3}{|c|}{$\begin{array}{c}\text { DCIS Diagnosed } \\
1987-2008\end{array}$} & \multicolumn{3}{|c|}{$\begin{array}{c}\text { DCIS Diagnosed } \\
2009-2017\end{array}$} & \multicolumn{3}{|c|}{ Whole Cohort } \\
\hline & $\begin{array}{c}\text { Hazard } \\
\text { Ratio }\end{array}$ & $95 \% \mathrm{CI}$ & $\begin{array}{c}\mathrm{p}- \\
\text { value }\end{array}$ & $\begin{array}{c}\text { Hazard } \\
\text { Ratio }\end{array}$ & $95 \% \mathrm{CI}$ & $\mathrm{p}$-value & $\begin{array}{c}\text { Hazard } \\
\text { Ratio }\end{array}$ & $95 \% \mathrm{CI}$ & $\mathrm{p}$-value \\
\hline Patient age & 1.5 & $0.8-2.9$ & $\begin{array}{c}0.23 \\
3\end{array}$ & 1.6 & $0.6-4.4$ & 0.351 & 1.5 & $0.9-2.5$ & 0.143 \\
\hline $\begin{array}{l}\text { DCIS } \\
\text { presentation }\end{array}$ & 2.3 & $1.2-4.5$ & $\begin{array}{c}0.01 \\
4\end{array}$ & 1.9 & $0.6-6.1$ & 0.230 & 2.4 & $1.4-4.1$ & 0.001 \\
\hline $\begin{array}{l}\text { DCIS site } \\
\text { (extent) }\end{array}$ & 0.5 & $0.1-1.8$ & $\begin{array}{c}0.28 \\
9\end{array}$ & 0.8 & $0.3-2.7$ & 0.758 & 0.6 & $0.2-1.3$ & 0.158 \\
\hline DCIS size & 10.4 & $3.9-27.8$ & $\begin{array}{l}<0.0 \\
001\end{array}$ & 5.2 & $1.5-18.5$ & 0.010 & 9.7 & $4.4-21.5$ & 0.0001 \\
\hline $\begin{array}{l}\text { DCIS Nuclear } \\
\text { grade }\end{array}$ & 1.1 & $0.4-3.0$ & $\begin{array}{c}0.92 \\
9\end{array}$ & 3.1 & $0.8-11.9$ & 0.084 & 1.3 & $0.5-3.2$ & 0.590 \\
\hline $\begin{array}{l}\text { Comedo } \\
\text { necrosis }\end{array}$ & 1.6 & $0.7-3.5$ & $\begin{array}{c}0.26 \\
2\end{array}$ & 0.2 & $0.1-0.8$ & 0.028 & 0.9 & $0.5-1.8$ & 0.896 \\
\hline $\begin{array}{l}\text { DCIS } \\
\text { Histological } \\
\text { type }\end{array}$ & 1.3 & $0.7-2.4$ & $\begin{array}{c}0.49 \\
1\end{array}$ & 0.8 & $0.3-2.6$ & 0.748 & 0.9 & $0.5-1.6$ & 0.856 \\
\hline Margin status & 0.2 & $0.1-0.6$ & $\begin{array}{c}0.00 \\
2\end{array}$ & 1.1 & $3.6-7.3$ & $\begin{array}{c}<0.00 \\
01\end{array}$ & 0.3 & $0.1-0.7$ & 0.005 \\
\hline
\end{tabular}

$p$ values in bold are significant 
D)

\begin{tabular}{|c|c|c|c|c|c|c|c|c|c|}
\hline \multirow{2}{*}{ Parameter } & \multicolumn{3}{|c|}{$\begin{array}{c}\text { DCIS Diagnosed } \\
1987-2008\end{array}$} & \multicolumn{3}{|c|}{$\begin{array}{c}\text { DCIS Diagnosed } \\
2009-2017\end{array}$} & \multicolumn{3}{|c|}{ Whole Cohort } \\
\hline & $\begin{array}{c}\text { Hazard } \\
\text { Ratio }\end{array}$ & $95 \% \mathrm{CI}$ & $\begin{array}{c}\mathrm{p}- \\
\text { value }\end{array}$ & $\begin{array}{c}\text { Hazard } \\
\text { Ratio }\end{array}$ & $95 \% \mathrm{CI}$ & $\mathrm{p}$-value & $\begin{array}{c}\text { Hazard } \\
\text { Ratio }\end{array}$ & $95 \% \mathrm{CI}$ & $\mathrm{p}$-value \\
\hline Patient age & 0.7 & $0.1-5.4$ & $\begin{array}{c}0.73 \\
1\end{array}$ & 0.9 & $0.3-2.2$ & 0.771 & 1.2 & $0.7-2.1$ & 0.490 \\
\hline $\begin{array}{l}\text { DCIS } \\
\text { presentation }\end{array}$ & 1.8 & $0.9-3.6$ & $\begin{array}{c}0.08 \\
2\end{array}$ & 4.4 & $1.3-14.6$ & 0.017 & 2.1 & $1.2-3.7$ & 0.007 \\
\hline $\begin{array}{l}\text { DCIS site } \\
\text { (extent) }\end{array}$ & 1.1 & $0.3-4.3$ & $\begin{array}{c}0.84 \\
5\end{array}$ & 0.2 & $0.1-0.8$ & 0.023 & 0.6 & $0.3-1.4$ & 0.262 \\
\hline DCIS size & 4.1 & $1.6-10.9$ & $\begin{array}{c}0.00 \\
4\end{array}$ & 4.7 & $1.1-19.7$ & 0.034 & 4.2 & $1.9-9.4$ & 0.0002 \\
\hline $\begin{array}{l}\text { DCIS Nuclear } \\
\text { grade }\end{array}$ & 0.7 & $0.2-2.2$ & $\begin{array}{c}0.59 \\
6\end{array}$ & 1.2 & $0.3-4.1$ & 0.794 & 0.7 & $0.4-1.4$ & 0.297 \\
\hline $\begin{array}{l}\text { Comedo } \\
\text { necrosis }\end{array}$ & 2.3 & $0.9-5.2$ & $\begin{array}{c}0.05 \\
1\end{array}$ & 0.9 & $0.3-3.9$ & 0.950 & 2.0 & $1.1-3.9$ & 0.042 \\
\hline $\begin{array}{l}\text { DCIS } \\
\text { Histological } \\
\text { type }\end{array}$ & 1.3 & $0.7-2.6$ & $\begin{array}{c}0.35 \\
9\end{array}$ & 2.1 & $0.7-5.6$ & 0.162 & 1.8 & $1.1-2.9$ & 0.030 \\
\hline Margin status & 2.2 & $0.6-9.1$ & $\begin{array}{c}0.25 \\
7\end{array}$ & 0.3 & $0.1-4.5$ & 0.442 & 1.3 & $0.5-3.4$ & 0.626 \\
\hline $\begin{array}{l}\text { Type of re- } \\
\text { excision* }\end{array}$ & 4.8 & $2.4-9.5$ & $\begin{array}{c}0.00 \\
01\end{array}$ & 2.5 & $0.8-7.9$ & 0.119 & 3.3 & $1.9-5.7$ & 0.0001 \\
\hline
\end{tabular}

$p$ values in bold are significant

*Type of re-excision either another conservative surgery or completion mastectomy. 